DR LEE DUFFIELD was senior

lecturer in journalism at the

Queensland University of Technology

in Brisbane until 2017. He continues

to have a strong interest in new media, European media and development news in the Pacific.

\section{British bomb legacy lingers in the islands}

\section{Grappling With The Bomb: Britain's} Pacific H-bomb Tests, by Nic Maclellan. Canberra: ANU Press, 2017. 408 pages. ISBN 9781760461379/9781760461386.

$\mathrm{N}$ IC MACLELLAN's Grappling with the Bomb is an adroit and readable treatment of the story of the British nuclear testing programme predominantly in the South Pacific islands.

Its chief focus is the series of nine British nuclear tests at Malden and Christmas (Kiritimati) Islands between May 1957 and September 1958. They were then part of the Gilbert and Ellice Islands Colony (GEIC), which was divided into Kiribati and Tuvalu at independence. Malden and Christmas (Kiritimati) Islands are now part of Kiribati.

The main theme is built around a notion of 'perfidious Albion' that emerges unforced with the story of British policy makers, civil servants, scientists and the armed forces embarking on a prodigious logistical effort to

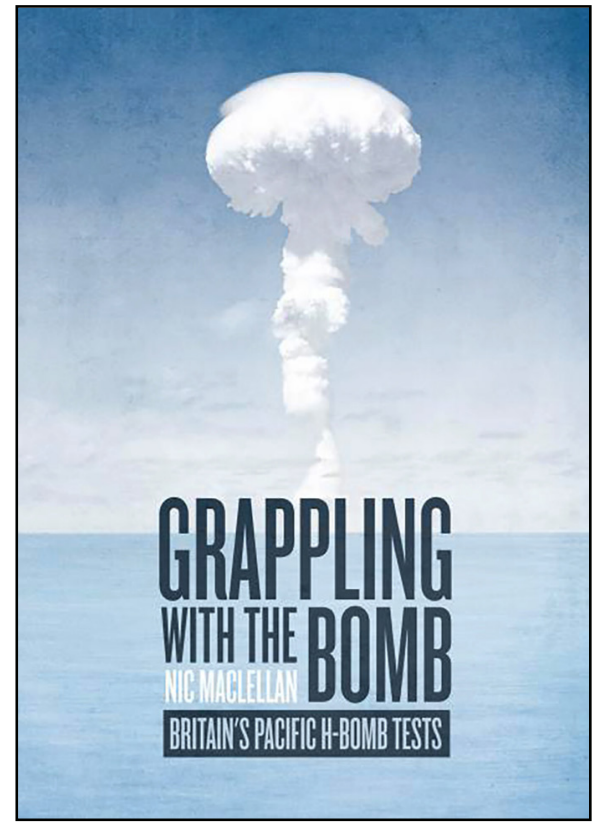

experiment with hellish weaponry at the 'end of the earth'.

In this they would show no particular care, not to say sometimes callous disregard for the effects on human health or the environment, modernday standards of self-determination for individuals or best practice in enacting policy.

The book documents feats of organisation that stretched the resources of the British Empire, where making ends meet required dragging in regional parties within a British sphere of influence or directly within colonial jurisdictions. Some 14,000 British personnel came to be involved plus hundreds more from the local Gilbertese population as well as the Australian, Fijian and New Zealand armed forces.

The story was marked by the insensitivity of British political leaders 
determined to maintain Great Power status through possession of the Hydrogen Bomb. Cold War secrecy blanketed efforts to establish accountability for all that happened, and official responsibility was studiously avoided when the human costs of nuclear testing began to mount.

An example of extreme complacency would seem to be the decision to move the GEIC testing programme, after the first three explosions, from Malden Island to the tip of Christmas Island itself, where all inhabitants of the military 'tent city' and the Gilbertese villagers were embarked on boats and ships in case of an accident for each test.

The island is small, 388 square kilometres, or about four percent of the size of Viti Levu in Fiji. The reason given for the move was to save time and money: the earlier tests had not reached target strength, so the programme had to be revived before an international test ban expected in 1958 .

Is it imaginable that setting off a hydrogen bomb at such proximity to habitation would be considered today? The Christmas Island site was handed to the United States and used for a further 24 tests in 1962.

Grappling with the Bomb is both scholarly and journalistic testing evidence from government archives, media reports and testimonies of those involved to produce a concise and plain-spoken overall account.

The unfolding of the nuclear test programme is dealt with chronologically, through chapters that give the perspective of i-Kiribati residents who would suffer enduring ill-health, similarly afflicted New Zealand and Fijian naval personnel, British air crew who flew through debris from explosions, politicians, Japanese fishermen working around the bomb zone, the British pacifist Harold Steele who campaigned to take a protest ship into the area and plantation owners and traders.

Two chapters called Interludes are given to interpretation of the factual material and presentation of reasoned argument. The first, on 'radiation, safety and secrecy', addresses the early dismissive attitudes about the risk from radiation, and lax or inadequate safety precautions.

At various points in the book words leap out from the archives. When British civil servants wanted to withhold public declaration of a test zone, one described American objections as 'tiresome' (p. 200). Another civil servant, exhibiting a kind of 'casual racism', (p. 4) wrote that islanders, being so close to nature, would not require the same protective clothing as 'civilised' (p. 8) observers.

The second Interlude chapter, on 'contested illnesses' brings the case up to date. Long battles with officialdom, frequently in courts in England and elsewhere, have not delivered compensation sought by sufferers with genetic disorders, cancers or other illnesses.

Officialdom would never budge on accepting irradiation from the nuclear tests as the cause, and benefitted from the ill-kept state of service records and gaps in medical research. Service 
personnel had been indemnified against injury, but that was interpreted as general risks of service, not potentially very expensive and unforeseen civil claims by veterans.

The American device of paying compensation on a 'presumptive list of illnesses', where absolute cause could not be proved, has not been adopted in Britain or the Commonwealth generally. The New Zealand government issued medals to its citizens and provided full military pensions, short of major individual compensation; the government of Fiji provided special capped grants to veterans and family members while attempting to pressure the United Kingdom to yield to appeals from its former colonial subjects.

Nic Maclellan, whose background is with the Fiji-based Pacific Concerns Research Centre (PCRC), has produced this book as an anniversary publication, marking 60 years since the first explosions. He acknowledges work done with colleagues on a 1990s book on the subject, with much new material now added.

While in general operating on the principle that facts will speak for themselves, he makes his point in this section on compensation:

The (British) government's cult of secrecy, so evident in the 1950s, has lingered into the 21 st century ... The problems of distance, time and official secrecy have hampered the efforts of elderly and often sick men. (pp. 322, 326)

The development of nuclear weapons was widely opposed from the early 1950s onwards by civil society and protest organisations in the United Kingdom and America, Australia and New Zealand, communities in the Pacific island colonies, a mass movement in Japan and elements of the Japanese government and the nonaligned states in Asia.

The book places the story of the Kiribati bomb tests against the wider story of the earlier testing on the Montebello Islands and at Maralinga in Australia; the extensive testing by the United States in Micronesia in the early 1950s; continued American explosions in the 1960s and 30 years of French tests up to 1996.

Two of the incidents recounted in this book raised the spectre of what would have happened if the bomb tests had gone wrong. Grappling with the Bomb co-opts the military code-name for the GEIC program, Operation Grapple. The biggest device tested was known as Grapple Y, a 2.8 megaton hydrogen bomb, detonated on April 28,1958 . It was set to have gone off at 2350 metres, but many accounts reported that it exploded as much as one kilometre closer to the surface. The retreating shockwave from the blast sucked up seawater and soil and deposited fallout across a vast area.

Grappling with the Bomb also refers to the infamous 'rogue' bomb Bravo detonated by the Americans at Bikini Atoll on 1 March 1954. Late weather reports warned of high altitude winds that might carry fallout beyond a prescribed control zone. The test went ahead anyway. 
It was a monstrous bomb, 15 megatons. The pollution from it affected northern parts of the Marshall Islands to the west especially Rongelap Atoll, causing its evacuation and conflict over claims for compensation of damage and loss of health that have lasted to the present day.

\section{As Indonesia struggles with sexual repression, two books are refocusing the conversation.}

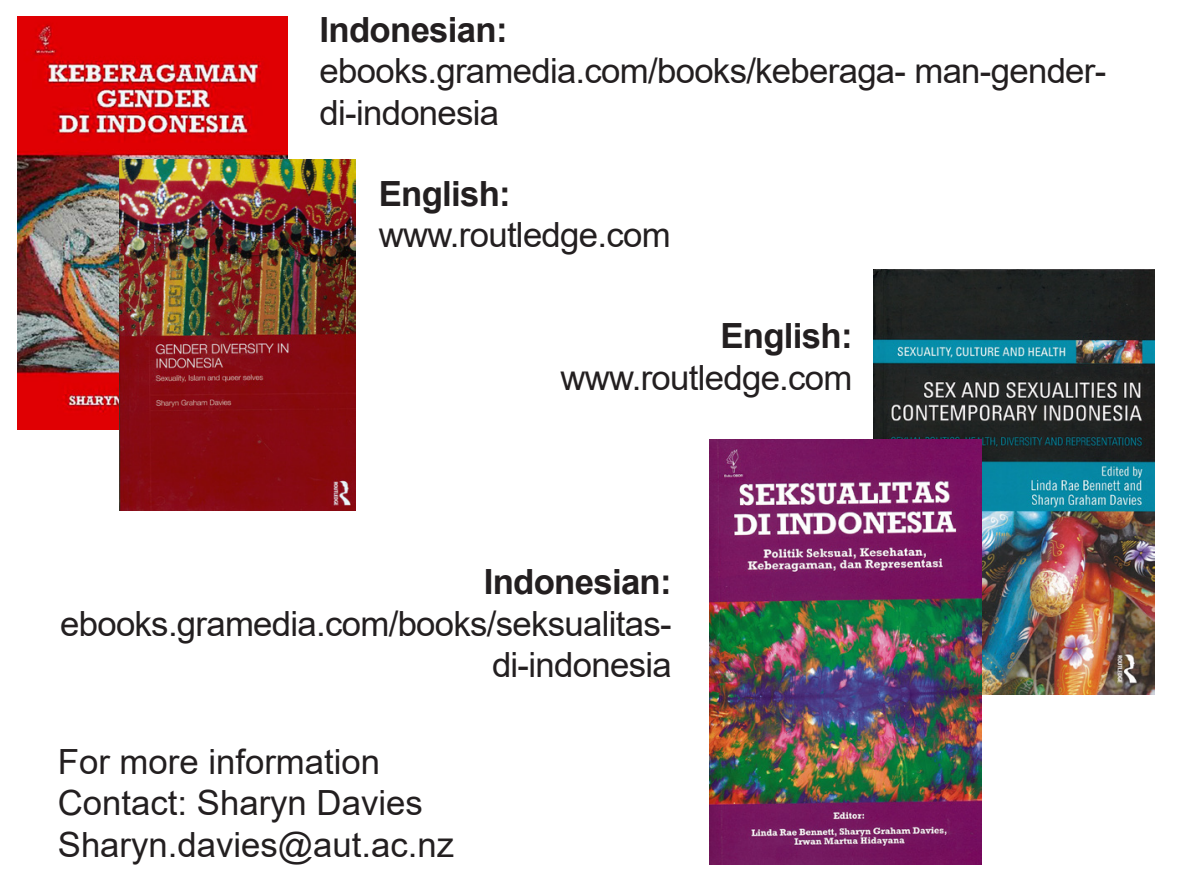

